\title{
Clinical patterns and complications of diabetes mellitus in India
}

\author{
Brig. H. B. LAL \\ F.R.C.P.E. \\ Consultant in Medicine
}

\author{
A. L. BAHL \\ M.D. \\ Assistant Surgeon (Physician) \\ R. N. Chugh \\ M.D. \\ Physician \\ K. P. Mathur \\ M.D. \\ A. S. Bhalla \\ M.B., B.S. \\ Physician \\ Assistant Surgeon \\ The Diabetic Clinic and Department of Medicine \\ Willingdon Hospital, New Delhi, India
}

\begin{abstract}
Summary
The records of 274 diabetics attending an outpatient clinic in New Delhi have been reviewed and the patients classified into four main types.

The relationship of the disease to nutritional, socio-economic and environmental factors has been discussed.

The incidence of complications in the various types is reported and the differences between them analysed.

\section{Introduction}

Diabetes mellitus till recently has beeen divided into two main types-the 'juvenile' and 'maturity onset' - on the basis of the age at onset, bodyweight, susceptibility to ketosis and response to insulin and oral therapy. Lawrence (1951) described a rare variety of lipo-atrophic diabetes characterized by earlier age of onset, loss of subcutaneous fat, rarity of ketosis and high insulin requirements. Hugh-Jones (1955) from Jamaica described the 'J-type' of diabetes mellitus which, although occurring in young and lean persons below 40 years of age, was not susceptible to ketosis, needed moderately large doses of insulin and did not respond to sulphonylurea compounds. Similar cases were later described from other tropical countries (Campbell \& McNeil, 1959 ; Cosnett, 1959 ; Tulloch, 1962).

Samaan \& Fraser (1963) used the term 'thinmiddle-aged diabetes' for a group of subjects weighing $98-115 \%$ of standard weight, showing low typical and atypical serum insulin-like activity and responding to sulphonylurea and biguanide c
\end{abstract}

compounds. Tripathi \& $\operatorname{Kar}$ (1965) refer to a similar variety as 'elderly-lean' type. Environmental, nutritional and socio-economic factors may be responsible for these variable patterns of disease. Furthermore, the acute and long-term sequelae may vary with the clinical disease-type.

\section{Material and methods}

Of the total clinic population (320 cases) only 274 diabetics in whom all the clinical findings and investigations were available formed the material for the present study. Diabetes mellitus was proved by a standard glucose tolerance test in the majority of cases. In others, fasting and post-prandial blood sugar levels were elevated along with glycosuria. The criteria of Joslin et al. (1959) were employed for the interpretation of these results.

For the classification of diabetes mellitus into various clinical types, the following criteria were employed:

Juvenile, growth onset or type 1. Disease starting below the age of 45 years, requiring insulin to prevent ketosis. The dose of insulin is often 40 units/day, but 35-60 units daily may be needed (Lawrence, 1951). These subjects are invariably underweight.

Lipo-plethoric, elderly-obese, maturity onset or type 2. The onset of disease is often after 40 years of age. These people are not prone to ketosis in the absence of infections, are insulininsensitive, obese and respond to dietary treatment or sulphonylurea.

J-type. Like 1, but there is no ketosis and sen- 
TABLE 1

Relationship of age at onset and sex to the duration of diabetes

\begin{tabular}{|c|c|c|c|c|c|c|c|c|c|c|c|c|c|c|}
\hline \multirow{3}{*}{$\begin{array}{c}\text { Duration of } \\
\text { diabetes } \\
\text { (years) }\end{array}$} & \multicolumn{12}{|c|}{ Age-groups (years) } & \multirow{2}{*}{\multicolumn{2}{|c|}{ Total cases }} \\
\hline & \multicolumn{2}{|c|}{ Below 19} & \multicolumn{2}{|c|}{$20-29$} & \multicolumn{2}{|c|}{$30-39$} & \multicolumn{2}{|c|}{$40-49$} & \multicolumn{2}{|c|}{$50-59$} & \multicolumn{2}{|c|}{60 and above } & & \\
\hline & $\mathbf{M}$ & $\mathbf{F}$ & $\mathbf{M}$ & $\mathbf{F}$ & $\mathbf{M}$ & $\mathbf{F}$ & $\mathbf{M}$ & $\mathbf{F}$ & $\mathbf{M}$ & $\mathbf{F}$ & $\mathbf{M}$ & $\mathbf{F}$ & $\mathbf{M}$ & $\mathbf{F}$ \\
\hline Below 1 & 1 & - & 3 & 2 & 8 & 10 & 22 & 12 & 24 & 9 & 5 & 2 & 63 & 35 \\
\hline $1-5$ & 2 & - & 3 & 2 & 7 & 8 & 22 & 11 & 15 & 10 & 6 & 3 & 55 & 34 \\
\hline $6-10$ & - & - & 2 & - & 5 & 7 & 7 & 13 & 9 & 3 & 4 & - & 27 & 23 \\
\hline $11-15$ & - & - & - & - & 3 & 6 & 5 & 5 & 2 & 1 & 1 & - & 11 & 12 \\
\hline $16-20$ & - & - & - & 1 & 2 & 1 & 2 & 1 & - & - & - & - & 4 & 3 \\
\hline 21 and above & - & - & - & 2 & 3 & 1 & 1 & - & - & - & - & - & 4 & 3 \\
\hline Total diabetics & 3 & - & 8 & 7 & 28 & 33 & 59 & 42 & 50 & 23 & 16 & 5 & 164 & 110 \\
\hline
\end{tabular}

sitivity to insulin is low. These diabetics are thin and often need more than 80 units of insulin per day.

Elderly-lean. Like type 2, underweight at the time of onset, can be controlled with sulphonylurea compounds. In this study, weights ranged from 90 to $109 \%$ of standard weight.

The disease was considered to be controlled when fasting and post-prandial blood sugar values were below $140 \mathrm{mg} / 100 \mathrm{ml}$ (Folin-Wu, quoted by Hawk, Oser \& Summerson, 1947) and the urine free of glucose.

Hypertension was presumed to be present if the blood pressure exceeded $150 \mathrm{mmHg}$ systolic and $90 \mathrm{mmHg}$ diastolic (patients with unequivocal hypertension before cardiac infarction were included even if their blood pressure on admission was below these limits). Coronary heart disease was considered to be present (Lal \& Bahl, 1967) if an unequivocal history of angina pectoris (even with a normal electrocardiogram), coronary insufficiency or myocardial infarction was present (based on clinical and electrocardiographic findings as well as SGOT elevations). Diabetic nephropathy was considered to be present when the criteria of Clark \& Skillern (1955) were fulfilled. Peripheral neuropathy was diagnosed when a history of paraesthesiae and/or changes in the deep reflexes, especially knee and ankle, were present with or without objective sensory impairment (Bahl, Khosla \& Caroli, 1967). Constipation, diarrhoea or postural hypotension were taken as evidence of autonomic neuropathy.

\section{Observations}

The relationship of the age at onset to the duration of diabetes mellitus is shown in Table 1 . The majority of the cases were in the age-group 40-49 years. The male and female ratio is $1: 0.88$ in the third decade rising to $1: 0.31$. in the age-group 60 years and above. No diabetic manifested the disease below 15 years of age. Male diabetics (59.9\%) outnumbered female diabetics $(40 \cdot 1 \%)$. Only in one case did diabetes start after the age of 70 years.

The relationship of the socio-economic status to the clinical pattern of diabetes is shown in Table 2. Most of the subjects in this study were non-vegetarian $(63.4 \%)$. The high-income group had a fairly balanced diet, whereas the lowincome group had an average of 1500-2800 calories daily on gross analysis, with a deficiency of protein and vitamins. Table 2 also shows the classification of the patterns of diabetes. Figs. 1 and 2 depict the relationship of age at onset,

TABLE 2

Socio-economic status of diabetics

\begin{tabular}{|c|c|c|c|c|c|c|c|c|c|c|c|}
\hline \multirow{2}{*}{$\begin{array}{c}\text { Monthly } \\
\text { income } \\
\text { (rupees) }\end{array}$} & \multirow{2}{*}{$\underset{\text { group }}{\text { SES }}$} & \multicolumn{8}{|c|}{ Clinical types of diabetes mellitus } & & \\
\hline & & \multicolumn{2}{|c|}{ Type 1} & \multicolumn{2}{|c|}{ J-type } & \multicolumn{2}{|c|}{ Elderly-lean } & \multicolumn{2}{|c|}{ Elderly-obese } & \multicolumn{2}{|c|}{ Total diabetics } \\
\hline $\begin{array}{l}150 \text { and below } \\
151-500 \\
501 \text { and above }\end{array}$ & $\begin{array}{l}\text { Low } \\
\text { Middle } \\
\text { High }\end{array}$ & $\begin{array}{r}16 \\
6 \\
14\end{array}$ & $\begin{array}{r}26 \cdot 6 \\
5 \cdot 3 \\
13 \cdot 9\end{array}$ & $\begin{array}{l}7 \\
5 \\
4\end{array}$ & $\begin{array}{r}11 \cdot 6 \\
4 \cdot 4 \\
4 \cdot 0\end{array}$ & $\begin{array}{l}10 \\
36 \\
25\end{array}$ & $\begin{array}{l}16 \cdot 6 \\
31 \cdot 9 \\
24 \cdot 7\end{array}$ & $\begin{array}{l}27 \\
66 \\
58\end{array}$ & $\begin{array}{l}45 \cdot 0 \\
58 \cdot 4 \\
57 \cdot 4\end{array}$ & $\begin{array}{r}60 \\
113 \\
101\end{array}$ & $\begin{array}{l}21 \cdot 8 \\
41 \cdot 7 \\
36 \cdot 9\end{array}$ \\
\hline
\end{tabular}




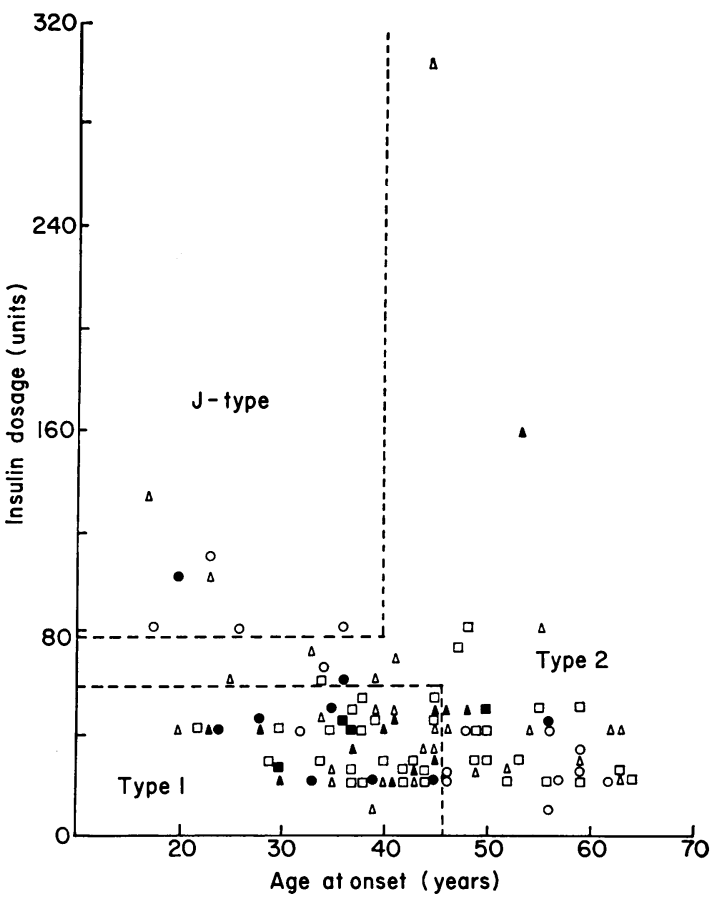

FIG. 1. Relationship of age at onset of diabetes mellitus, requirements of insulin and the percentage of standard weight. Solid symbols, ketosis; open symbols, no ketosis. $O, 50-80 \% ; \triangle, 90-109 \% ; \square, 110 \%$ or more of standard weight.

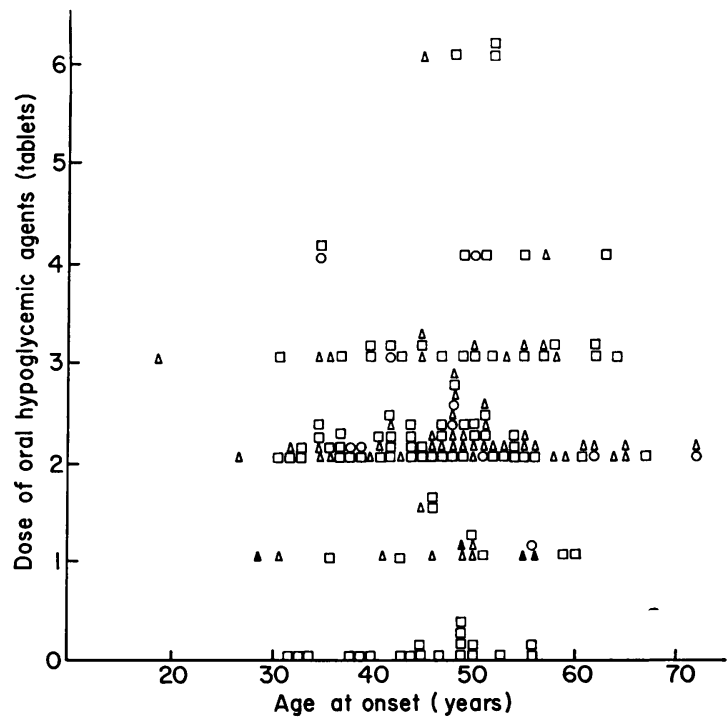

FIG. 2. Relationship of age at onset of diabetes mellitus, percentage of standard weight and requirements of oral hypoglycemic agents. (One tablet represents $250 \mathrm{mg}$ tolbutamide, $125 \mathrm{mg}$ chlorpropamide, $25 \mathrm{mg}$ phenformin or a combination of $25 \mathrm{mg}$ phenformin and $125 \mathrm{mg}$ chlorpropamide.) Standard weight: $O$, no ketosis 50 $80 \%$; $\triangle$, no ketosis $90-109 \%$; $\triangle$, ketosis $90-109 \%$; $\square$, no ketosis $110 \%$ or more. requirements of insulin or hypoglycemic agents and percentage of standard weight. Allowing a range of $\pm 10 \%$ of standard weight for normal, $138(50 \cdot 4 \%)$ diabetics were obese and 35 $(12 \cdot 8 \%)$ were underweight.

The incidence of underweight and overweight diabetics was almost equal in the two sexes (14.6 and $50.0 \%$ in males, 10.0 and $50.9 \%$ in females, respectively). In the age-group 20 years and over, obese diabetics predominated over underweight diabetics $(50.4$ and $12.4 \%$, respectively) as seen in Fig. 3. Fig. 4 shows the re-

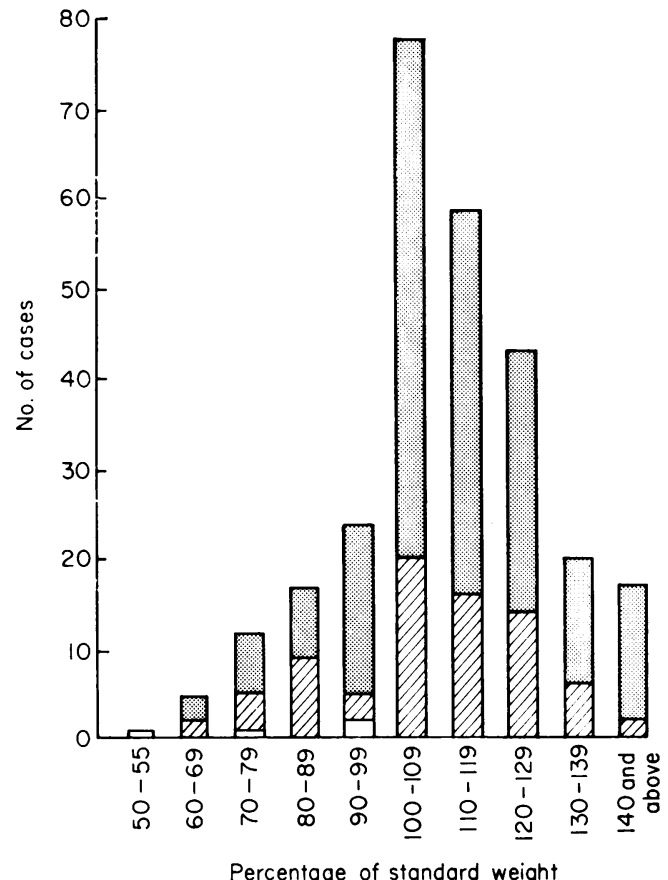

FIG. 3. Relationship of age ac onset of diabetes mellitus to the percentage of standard weight. Open columns, below 20 years; cross-hatched columns, 20-39 years; stippled columns, 40 years and above.

lationship of sex to the percentage of standard weight. The severity of diabetes mellitus as judged from post-prandial blood sugar levels is shown in Table 3.

Type 1 and J-type diabetics are demarcated by interrupted lines (Fig. 1). Although only seven cases fulfilled the criteria for J-type diabetes, nine more patients who were of standard weight or below with onset of diabetes up to 55 years of age, insulin requirements more than 60 units/day and no ketosis except in the presence of infection have also been included under 
J-type. Similarly twenty-nine diabetics fulfilled the criteria for being included in type 1 diabetes. Seven more diabetics who were underweight or had standard weight, with age of onset up to 50 years and with other characteristics of type 1 , have been included in this clinical type.

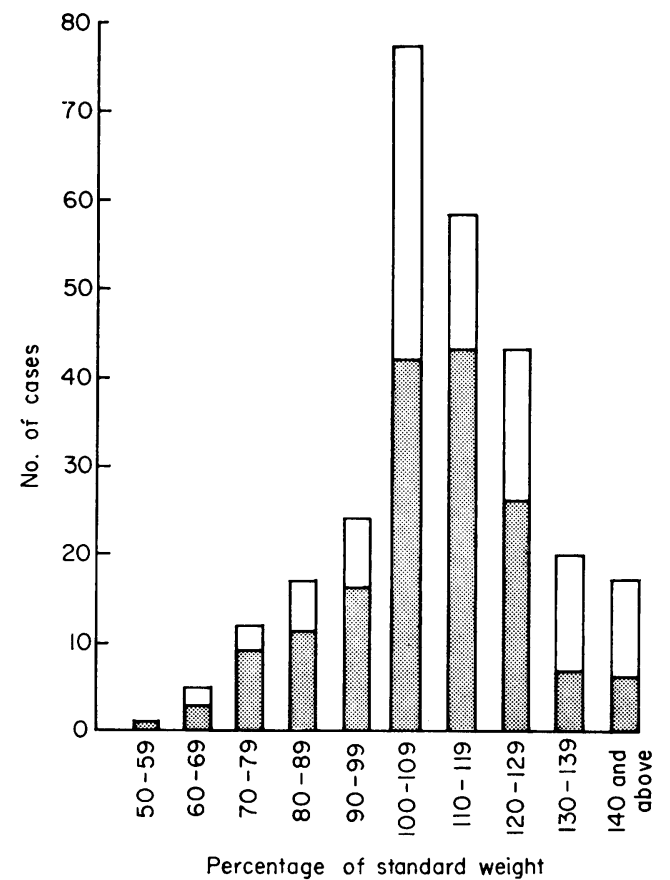

FIG. 4. Relationship of sex to the percentage of standard weight in ldiabetics. Stippled columns, males; open columns, females.

TABLE 3

Severity of diabetes as judged from post-prandial blood sugar levels

$\begin{gathered}\text { Post-prandial } \\ \text { blood sugar }\end{gathered}$ No. of cases
$(\mathrm{mg} / 100 \mathrm{ml})$

\begin{tabular}{lrr}
\hline Below 200 & 194 & $70 \cdot 8$ \\
$200-249$ & 40 & $14 \cdot 5$ \\
$250-299$ & 25 & $9 \cdot 1$ \\
300 and above & 15 & $5 \cdot 5$ \\
\hline
\end{tabular}

As seen from Fig. 1, seventy-one patients had weights ranging from 90 to $109 \%$ of standard weight and were controlled with sulphonylurea or diguanide compounds. These patients have been classified as 'lean diabetics responsive to oral hypoglycaemic agents'. The terms 'thinmiddle-aged diabetics' and 'elderly-lean diabetics' used to describe such patients appear mis- nomers when it is realized that in thirteen $(18.3 \%)$ of seventy-one such diabetics the onset of the disease was below the age of 39 years. One patient with onset of the disease at 22 years was markedly obese and responded to dietetic treatment alone.

Liver biopsy done in eight cases with type 1 diabetes showed fatty changes in four patients. Of these, one case each had periportal fibrosis, periportal infiltration by mononuclear cells and early cirrhosis. Dilatation of the central veins was seen in one case. Biopsy of the liver showed normal histology in three patients. Fatty changes in the liver cells were also present in J-type (two of three cases), elderly-lean (two of three cases), and elderly-obese (four of five cases) diabetics. Liver function tests done in these patients revealed elevation of serum glutamic oxalic transaminase and serum glutamic pyruvic transaminase in three cases, prolongation of prothrombin time in three cases and increased serum alkaline phosphatase in one case; there were abnormalities of flocculation tests in three cases with juvenile diabetes. In one obese and one J-type diabetic, some abnormality of liver function tests could be demonstrated.

\section{Discussion}

In a majority of diabetics (36.9\%), diabetes mellitus started in the fifth decade of life. Tripathi \& Kar (1965) observed the age at onset to be 35-44 and 45-54 years in a majority of the hospital and domiciliary patients, respectively. Male predominance in Indian diabetics is well known (Banerjea, Roy \& Mukherjea, 1960 ; Pathania \& Sachar, 1961 ; Bahl, 1963 ; Tripathi \& Kar, 1965 ; Mukherjee et al., 1966 ; Lal \& Bahl, 1967). The duration of the disease was 5 years or less in $69 \cdot 1 \%$. Most diabetics $(70 \cdot 1 \%$ ) had a post-prandial blood sugar of $200 \mathrm{mg} / 100 \mathrm{ml}$ or below.

There were $50.4 \%$ overweight and $12.8 \%$ underweight subjects when standard weight was considered to be within $\pm 10 \%$ of normal. In studies on Indians (Tripathi \& Kar, 1965) and Natal Indians (Cosnett, 1959) the corresponding incidences were 32 and $52 \%$ and 32 and $25 \%$ On restricting the standard weight-range to limits of $\pm 5 \%$, the overweight and underweight diabetics formed 54.9 and $14.9 \%$. The figures in other series from Ceylon (De Zoysa, 1951) and from the United States (Joslin et al., 1959) are 20 and $68 \%$ and 77 and $8 \%$, respectively. The sex incidence of underweight and overweight diabetics did not differ significantly in contrast with the preponderance of female lipoplethoric diabetics in England (Lawrence, 1951). 
TABLE 4

Complications of diabetes in various clinical types

\begin{tabular}{|c|c|c|c|c|c|c|c|c|c|c|}
\hline \multirow{3}{*}{ Complication } & \multicolumn{8}{|c|}{ Clinical types of diabetes mellitus } & \multirow{2}{*}{\multicolumn{2}{|c|}{$\begin{array}{c}\text { Total } \\
\text { diabetics }\end{array}$}} \\
\hline & \multicolumn{2}{|c|}{ Type 1} & \multicolumn{2}{|c|}{ J-type } & \multicolumn{2}{|c|}{ Elderly-lean } & \multicolumn{2}{|c|}{ Elderly-obese } & & \\
\hline & No. & $\%$ & No. & $\%$ & No. & $\%$ & No. & $\%$ & No. & $\%$ \\
\hline Total cases & 36 & $13 \cdot 1$ & 16 & $5 \cdot 9$ & 71 & $25 \cdot 9$ & 151 & $55 \cdot 1$ & 274 & $100 \cdot 0$ \\
\hline $\begin{array}{l}\text { A. Infections } \\
\text { 1. Pyogenic } \\
\text { 2. Tubercular } \\
\text { 3. Urinary tract } \\
\text { 4. Fungal }\end{array}$ & $\begin{array}{r}14 \\
2 \\
1 \\
6\end{array}$ & $\begin{array}{r}38 \cdot 9 \\
5 \cdot 5 \\
2 \cdot 8 \\
16 \cdot 6\end{array}$ & $\begin{array}{l}2 \\
- \\
- \\
3\end{array}$ & $\begin{array}{c}12 \cdot 5 \\
- \\
- \\
18 \cdot 7\end{array}$ & $\begin{array}{r}13 \\
- \\
3 \\
9\end{array}$ & $\begin{array}{r}18 \cdot 3 \\
- \\
4 \cdot 2 \\
12 \cdot 7\end{array}$ & $\begin{array}{r}22 \\
9 \\
4 \\
19\end{array}$ & $\begin{array}{r}14.6 \\
5.9 \\
2.6 \\
12.6\end{array}$ & $\begin{array}{r}51 \\
11 \\
8 \\
37\end{array}$ & $\begin{array}{r}18 \cdot 6 \\
4.0 \\
2.9 \\
13 \cdot 5\end{array}$ \\
\hline $\begin{array}{l}\text { B. Degenerative } \\
\text { 1. Coronary heart disease } \\
\text { 2. Hypertension } \\
\text { 3. Nephropathy } \\
\text { 4. Albuminuria } \\
\text { 5. Peripheral neuropathy } \\
\text { 6. Autonomic neuropathy } \\
\text { 7. Retinopathy } \\
\text { 8. Cerebrovascular disease } \\
\text { 9. Gangrene }\end{array}$ & $\begin{array}{c}10 \\
10 \\
3 \\
4 \\
14 \\
3 \\
7^{*} \\
1 \\
-\end{array}$ & $\begin{array}{r}27 \cdot 8 \\
27 \cdot 8 \\
8 \cdot 3 \\
11 \cdot 1 \\
38 \cdot 9 \\
8 \cdot 3 \\
21 \cdot 9 \\
2 \cdot 8 \\
-\end{array}$ & $\begin{array}{l}3 \\
2 \\
2 \\
2 \\
3 \\
1 \\
3 \\
- \\
-\end{array}$ & $\begin{array}{r}18 \cdot 7 \\
12 \cdot 5 \\
12 \cdot 5 \\
12 \cdot 5 \\
18 \cdot 7 \\
6 \cdot 2 \\
18 \cdot 7 \\
- \\
-\end{array}$ & $\begin{array}{c}18 \\
15 \\
6 \\
11 \\
34 \\
6 \\
14 \dagger \\
3 \\
2\end{array}$ & $\begin{array}{r}25 \cdot 3 \\
21 \cdot 1 \\
8 \cdot 4 \\
15 \cdot 5 \\
47 \cdot 9 \\
8 \cdot 4 \\
21 \cdot 2 \\
4 \cdot 2 \\
2 \cdot 8\end{array}$ & $\begin{array}{l}30 \\
25 \\
11 \\
20 \\
57 \\
20 \\
33 \ddagger \\
4 \\
2\end{array}$ & $\begin{array}{r}19 \cdot 9 \\
16 \cdot 6 \\
7 \cdot 3 \\
13 \cdot 2 \\
37 \cdot 8 \\
13 \cdot 2 \\
24 \cdot 6 \\
2 \cdot 6 \\
1 \cdot 3\end{array}$ & $\begin{array}{c}61 \\
52 \\
22 \\
37 \\
108 \\
30 \\
57 \S \\
8 \\
4\end{array}$ & $\begin{array}{r}22 \cdot 3 \\
18 \cdot 9 \\
8 \cdot 0 \\
13 \cdot 5 \\
39 \cdot 4 \\
10 \cdot 9 \\
23.0 \\
2.9 \\
1.5\end{array}$ \\
\hline $\begin{array}{l}\text { C. Miscellaneous } \\
\text { 1. Impotence } \\
\text { 2. Cataract } \\
\text { 3. Hepatomegaly } \\
\text { 4. Anemia } \\
\text { 5. Avitaminosis } \\
\text { 6. Ketosis without infection } \\
\text { 7. Ketosis with infection }\end{array}$ & $\begin{array}{r}5 \\
2 \\
\overline{3} \\
\overline{1} \\
18 \\
11\end{array}$ & $\begin{array}{r}13 \cdot 8 \\
5 \cdot 5 \\
- \\
8.3 \\
- \\
50 \cdot 0 \\
30 \cdot 5\end{array}$ & $\begin{array}{l}2 \\
1 \\
3 \\
3 \\
2 \\
- \\
2\end{array}$ & $\begin{array}{r}12 \cdot 5 \\
2 \cdot 8 \\
18 \cdot 7 \\
18 \cdot 7 \\
12 \cdot 5 \\
- \\
12 \cdot 5\end{array}$ & $\begin{array}{r}10 \\
9 \\
6 \\
17 \\
4 \\
- \\
9\end{array}$ & $\begin{array}{r}14 \cdot 1 \\
12 \cdot 7 \\
8 \cdot 4 \\
23 \cdot 9 \\
5 \cdot 6 \\
- \\
12 \cdot 7\end{array}$ & $\begin{array}{r}17 \\
9 \\
13 \\
9 \\
6 \\
- \\
17\end{array}$ & $\begin{array}{r}11 \cdot 3 \\
5 \cdot 9 \\
8.6 \\
5 \cdot 9 \\
3.9 \\
- \\
11 \cdot 3\end{array}$ & $\begin{array}{l}34 \\
21 \\
22 \\
32 \\
12 \\
18 \\
39\end{array}$ & $\begin{array}{r}12 \cdot 4 \\
7 \cdot 7 \\
8 \cdot 0 \\
11 \cdot 7 \\
4 \cdot 4 \\
6 \cdot 6 \\
14 \cdot 2\end{array}$ \\
\hline
\end{tabular}

* Of thirty-two type 1 diabetics in whom fundus was properly examined.

$\dagger$ Of sixty-six elderly-lean diabetics in whom fundus was properly examined.

$\ddagger$ Of 134 elderly-obese diabetics in whom fundus was properly examined.

$\S$ Of 248 total diabetics in whom fundus was properly examined.

No case of diabetes mellitus was encountered in the first decade of life, compared to nearly $5 \%$ of such patients in the Western countries (Joslin et al., 1959). In the second decade of life, only three $(1 \cdot 1 \%)$ patients were seen, which is much lower than the $8 \%$ incidence elsewhere (Joslin et al., 1959). The infrequency of juvenile diabetics with ketosis and coma in India was emphasized at the 75th Annual Meeting of the British Medical Association held in 1907.

The incidence of J-type and elderly-lean diabetics in this study is much lower than in the series reported by Tripathi \& Kar (1965). Contary to the findings of these authors, the elderlylean type of diabetes was more prevalent in the better socio-economic strata. J-type diabetes was rare in high-income groups and juvenile diabetes was more prevalent in low-income groups. De Zoysa (1951) and Tripathi \& Kar (1965) explained the differences in clinical patterns of diabetes in the tropics on the basis of undernutrition and low fat-intake. Hugh-Jones (1955) and Cosnett (1959), however, considered that the levels of nutrition are not responsible for these differences in the clinical patterns. The incidence of underweight diabetics in the tropics may be due to differences in susceptibility, as is also suggested by the observations of Cosnett (1957) that Indians in Natal manifested marked differences in the incidence of diabetes, factors like climate and nutrition remaining constant. Possibly a particular diabetic factor such as an intake of herbs may be a causative factor (HughJones, 1955 ; Cosnett, 1959), but does not appear likely in our study.

The finding of fatty change in the liver in type 2 diabetes agrees with that of Hugh-Jones (1955) and of Bearn, Billing \& Sherlock (1951). The same authors reported normal liver histology in type 1 diabetes, which is in sharp contrast with our observations of fatty changes in hepatic cells even in these cases.

The incidence of complications in this study is similar to that reported in a previous publication from this clinic (Lal, Chugh \& Bahl, 1966). Pyogenic infections, ketosis, coronary heart 
disease and hypertension were more frequent in type 1 diabetics. Fungal infections, nephropathy, hepatomegaly and avitaminosis were more often detected in J-type diabetes. Elderly-lean diabetics appeared to be more prone to urinary tract infection, neuropathy, gangrene, cerebrovascular disease, anaemia and cataract. Tubercular infections and autonomic neuropathy were the most frequently noticed complications of the elderlyobese type of diabetes mellitus. Impotence, retinopathy and albuminuria affected all types of diabetics with almost equal frequency. Cholecystitis was not observed in any of the cases studied. The rarity of gall-bladder disease was also observed among Natal Indians (Cosnett, 1957). Gangrene was observed in elderly-lean and elderly-obese diabetics only (Table 4).

It is difficult to offer an explanation for these differences in the incidence of complications in various types of diabetes. Susceptibility to various sequelae may be due to the same factors which determine the clinical patterns of diabetes.

\section{Acknowledgments}

Thanks are due to Dr Harbans Lal, Dr H. M. Chowdhary, Dr C. G. Keswani, Dr (Mrs) B. Caroli, Dr Banerjee of the diabetic clinic for their valuable help in conducting this study. We gratefully acknowledge the assistance of $\mathrm{Mr} R$. C. Dhawan of National Physical Laboratories, New Delhi, for his help with the illustrations.

\section{References}

BAHL, A.L. (1963) Vascular disease in diabetes mellitus. Thesis submitted for the degree of M.D. (Medicine), University of Delhi (India).

Bahl, A.L., Khosla, H.L. \& Caroli, R.K. (1967) A study of the involvement of nervous system in diabetes with special reference to neuropathy. Indian med. Gaz. 10, 24.

BanerJeA, J.C., RoY, H.K. \& MukherJeA, A.B. (1960) Cardiovascular complications in diabetes mellitus. J. Ass. Phycns, India, 8, 283.
Bearn, A.G., Billing, B.H. \& Sherlock, S. (1951) Hepatic glucose output and insulin sensitivity in diabetes mellitus. Lancet, ii, 698.

Campbell, G.D. \& McNeIL, W.G. (1959) Diabetes in the tropics. Brit. med. J. i, 633.

Clark, A.M. \& SKILleRN, P.G. (1955) Intercapillary glomerulosclerosis. Med. Clin. N. Amer. 39, 1001.

CosNeTT, J.E. (1957) Illness among Natal Indians-A survey of hospital admissions. S. Afr. med. J. 31, 1109.

CosNeTT, J.E. (1959) Diabetes among Natal Indians. Brit. med. J. i, 187.

DE ZoYsA, V.P. (1951) Clinical variations of the diabetic syndrome in a tropical country (Ceylon). Arch. intern. Med. 88, 812.

Discussion on Diabetes in the Tropics (1907) 75th Annual meeting of British Medical Association. Brit. med. J. i, 1051.

HaWk, P.B., Oser, P.L. \& Summerson, W.H. (1947) Practical Physiological Chemistry, 12th edn. Blakiston, Philadelphia.

Hugh-Jones, P. (1955) Diabetes in Jamaica. Lancet, ii, 891.

Joslin, E.P., Root, H.F., White, P. \& Marble, A. (1959) The Treatment of Diabetes Mellitus, 10th edn. Lea \& Febiger, Philadelphia.

LAL, H.B. \& BAHL, A.L. (1967) Association of diabetes mellitus, hypertension and coronary heart disease. Indian Heart J. 19, 96.

Lal, H.B., Chugh, R.N. \& Bahl, A.L. (1966) Clinical study of diabetics-A preliminary report. Willingdon Hospital Ann. J. 1, 22.

LAWRENCE, R.D. (1951) Types of human diabetes. Brit. med. J. i, 373.

Mukherjee, A.B., Pandey, G.C., BanerJea, N. \& Dasgupta, M.K. (1966) Clinical observations on cardiovascular com-êt plications of diabetes mellitus. J. Indian med. Ass. 47, 597.

Pathania, N.S. \& SAChaR, R.S. (1961) Cardiovascular complications of diabetes mellitus. Brit. med. J. i, 1505.

SamaAN, N. \& Fraser, R. (1963) 'Typical' and 'atypical' serum insulin like activity in untreated diabetes mellitus. Lancet, ii, 311.

Tripathi, B.B. \& KAR, K.C. (1965) Observations on clinical patterns of diabetes in India. Diabetes, 14, 404.

Tulloch, J.A. (1962) Diabetes Mellitus in the Tropics. Livingstone, London. 